\title{
Conditions and Hardships Related to Pharmacists' Provisions of Anti-Doping Activities in Japan
}

\author{
Rie Nakajima, Naoko Onuma, Fumiyuki Watanabe and Miwako Kamei \\ School of Pharmacy, Nihon University \\ Rie Nakajima (nakajima.rie@ nihon-u.ac.jp)
}

[Received April 27, 2020; Accepted August 19, 2020; Published online September 4, 2020]

\begin{abstract}
We conducted a cross-sectional survey of pharmacists working in hospitals and community pharmacies in Japan to assess anti-doping activities, aiming to improve athletes' medication support. An internet survey was conducted anonymously using a structured questionnaire, with items regarding the respondent's basic information, their collaboration with other healthcare professionals, and their experiences with medication support for athletes. Of the 841 pharmacists who completed the survey, 21.4\% had experienced anti-doping inquiries from athletes, and $18.7 \%$ of non-sports pharmacists had experienced medication consultations with athletes. Significantly more accredited sports pharmacists than non-sports pharmacists referred to the World Anti-Doping Agency's (WADA) Prohibited List $(p=0.009)$, the Global Drug Reference Online (Global DRO) $(p<0.001)$, and the Japan Pharmaceutical Association's anti-doping hotline $(p=0.001)$. A significantly greater proportion of male pharmacists $(p<0.001)$, accredited sports pharmacists $(p<0.001)$, and pharmacists who cooperated with other healthcare professionals, such as medical doctors and dietitians $(p<0.001)$, reported that they were confident handling anti-doping inquiries. Although pharmacists generally conduct consultations with athletes, further education is needed, as pharmacists have trouble effectively providing information on doping prevention. Ideally, athletes should consult with accredited sports pharmacists who have undergone continued anti-doping education. Moreover, multi-sectoral collaboration among healthcare professionals is vital for the effective health support of athletes.
\end{abstract}

Key words: anti-doping, athlete, medication support, pharmacist

\section{Introduction}

Anti-doping constitutes a range of activities aimed at eliminating doping in sports, as well as protecting clean athletes and the integrity and values of sports (Tokyo 2020, 2020). The 2020 Tokyo Olympics and Paralympics emphasizes the concept of 'sports and health' as part of the five Olympic legacies. This concept includes the promotion of anti-doping activities on an international level to protect the integrity of sports (Tokyo 2020, 2020). Thus, Japan, the host country of the 2020 Tokyo Olympics and Paralympics, has implemented anti-doping activities, to be continued even after the Olympics and Paralympics. However, worldwide reports of doping violations by top athletes have not significantly declined (World Anti-Doping Agency, 2019).

Unlike the general public, professional athletes are obligated to abstain from a number of chemicals designated as banned substances and must remain vigilant against "inadvertent doping" (i.e. the accidental or unintentional use of banned substances) (MartinezSanz et al., 2017). Doping tests are becoming more common in athletic competitions, and younger athletes are increasingly being targeted for such tests; indeed, in 2019, 38 track and field competitions held in Japan conducted doping tests (Japan Anti-doping Agency, 2020a). Given the growing awareness of athlete doping, many athletes are expressing concern about whether their medicines or nutritional supplements contain banned substances.

Our previous study revealed that young athletes exhibit unique health behaviors (Nakajima et al., 2018). For example, they tend to take nutritional supplements to build their body in a way that best suits their chosen sport. Some athletes refrain from taking too much 
medication due to a fear of inadvertent doping, which suggests that it is necessary to teach athletes about nutrition and how to efficiently cope with health problems.

As a precautionary measure against doping, Japan launched the Sports Pharmacist system in 2009. This is a qualification system whereby a pharmacist completes a course on anti-doping (e.g., the latest prohibited drug list) provided by the Japan Anti-Doping Agency (JADA). To maintain accreditation, sports pharmacists take an annual e-learning course for antidoping updates. Sports pharmacists primarily engage in consultations with athletes who want to know whether a given medicine contains a substance that may constitute doping (Japan Anti-doping Agency, 2020b). The prohibited substances specified by the World Anti-Doping Agency (WADA) are constantly changing, and the list itself is becoming increasingly complicated; as a result, it is difficult for athletes alone to judge whether drugs contain prohibited substances (World Anti-Doping Agency, 2020). While sports pharmacists are expected to aid athletes in this regard, not all medical facilities have, or are affiliated with, sports pharmacies, which may limit athletes' access to these services. Overall, however, the current anti-doping measures for athletes in Japan remain sufficient.

For all pharmacists, anti-doping activities are important for promoting community health; these activities should not be limited to accredited sports pharmacists. According to a previous study, pharmacists are required to have anti-doping knowledge, regardless of whether they are certified as sports pharmacists (Shimokawa et al., 2014). However, we have little information on the daily anti-doping activities of general pharmacists. Therefore, we conducted a questionnaire survey on anti-doping activities among pharmacists working in hospitals and pharmacies to assess anti-doping activities and improve athletes' medication support.

\section{Methods}

\subsection{Survey methods}

The internet survey was conducted anonymously from February to March 2018 using a structured questionnaire. The survey respondents consisted of 4,455 pharmacists registered at an internet research company (3,382 worked in community pharmacies; 1,073 in hospitals). The questionnaire was distributed to all pharmacists simultaneously as a questionnaire titled, "Medication Support Activities for Athletes"; those who completed the entire questionnaire within the survey period were included in the analysis.

\subsection{Contents of the questionnaire}

The questionnaire contained items regarding the respondents' basic information, such as sex, age, place of work (hospital or pharmacy), and work area (metropolitan area or other area), as well as their accreditation status (sports or non-sports pharmacist) and their collaboration status with other healthcare professionals, including medical doctors and dieticians.

Questions related to current anti-doping activities, anti-doping consultation experiences, the types of medicines inquired about by athletes, anti-doping information sources, and pharmacists' knowledge of doping inquiry procedures and their confidence in handling athletes' anti-doping inquiries were included to clarify the respondents' daily anti-doping activities.

\subsection{Data analysis}

The survey results were analyzed via a simple tabulation of responses to each item. Additionally, participants' experiences with anti-doping activities according to sex, workplace, presence or absence of sports pharmacist accreditation, and their cooperation with other healthcare professionals were analyzed via the chi-square test. We employed SPSS Statistics 25 (SPSS, Inc., Chicago, IL, USA) for all analyses, with the significance level set at 5\%.

\subsection{Ethics}

The survey protocol adhered to the ethical guidelines for medical and health research involving human subjects and was approved by the ethical review board of Nihon University's School of Pharmacy (approval number: 17-017).

\section{Results}

A total of 841 pharmacists completed the questionnaire during the survey period, of which $503(59.8 \%)$ were male. The largest proportion of respondents were in their 40s $(\mathrm{n}=311,37.0 \%)$, followed by those in their 30s $(\mathrm{n}=294,35.0 \%)$ and $50 \mathrm{~s}(\mathrm{n}=156,18.5 \%)$. 
Nearly all the respondents $(n=675,80.3 \%)$ had worked for 11 years as pharmacists, and most worked in community pharmacies $(n=540,64.2 \%)$; the remaining 301 (35.8\%) worked in hospitals. Among all respondents, 120 (14.3\%) were accredited sports pharmacists. There was no difference in presence or ab- sence of cooperation with other healthcare professionals between pharmacists working in hospitals $(n=$ $68 / 301,22.6 \%)$ and those working in pharmacies $(\mathrm{n}=$ $124 / 540,23.0 \%)(\mathrm{p}=0.932)$.

Table 1 illustrates the backgrounds of the accredited sports pharmacists. Although these pharmacists

Table 1 Background of accredited sports pharmacists.

\begin{tabular}{|c|c|c|c|c|c|}
\hline & & \multirow[t]{2}{*}{$\begin{array}{l}\text { Total } \\
\text { (合計) }\end{array}$} & $\begin{array}{l}\text { Sports pharmacist } \\
\text { (スポーツファーマ } \\
\text { シスト認定あり) }\end{array}$ & $\begin{array}{l}\text { Non-sports pharmacist } \\
\text { (スポーツファーマ } \\
\text { シスト認定なし) }\end{array}$ & \multirow[t]{2}{*}{$\mathrm{p}$} \\
\hline & & & n $(\%)$ & n $(\%)$ & \\
\hline \multirow[t]{2}{*}{ Sex（性別） } & Male（男性） & 503 & $84(16.7 \%)$ & $419(83.3 \%)$ & \multirow{2}{*}{0.016} \\
\hline & Female（女性） & 338 & $36(10.7 \%)$ & $302(89.3 \%)$ & \\
\hline \multirow[t]{5}{*}{ Age（年代） } & 20s（20 代） & 38 & $4(10.5 \%)$ & $34(89.5 \%)$ & \multirow{5}{*}{0.323} \\
\hline & 30s（30 代） & 294 & $33(11.2 \%)$ & $261(88.8 \%)$ & \\
\hline & 40s（40 代） & 311 & $50(16.1 \%)$ & $261(83.9 \%)$ & \\
\hline & 50s（50 代） & 156 & $25(16.0 \%)$ & $131(84.0 \%)$ & \\
\hline & over 60 years（60 代以上） & 42 & $8(19.0 \%)$ & $34(81.0 \%)$ & \\
\hline \multirow[t]{2}{*}{ Place of work（勤務先） } & Hospital（病院） & 301 & $49(16.3 \%)$ & $252(83.7 \%)$ & \multirow{2}{*}{0.213} \\
\hline & Pharmacy（薬局） & 540 & $71(13.1 \%)$ & $469(86.9 \%)$ & \\
\hline \multirow[t]{2}{*}{ Area of work（勤務地域） } & Metropolitan area ${ }^{*}$ (都市圈) & 496 & $66(13.3 \%)$ & $430(86.7 \%)$ & \multirow{2}{*}{0.367} \\
\hline & Other area（都市圈以外） & 345 & $54(15.7 \%)$ & $291(84.3 \%)$ & \\
\hline
\end{tabular}

* Metropolitan (Capital and Kinki areas) includes Tokyo, Saitama, Chiba, Kanagawa, Ibaraki, Tochigi, Gunma, Yamanashi, Fukui, Mie, Shiga, Kyoto, Osaka, Hyogo, Nara, and Wakayama.

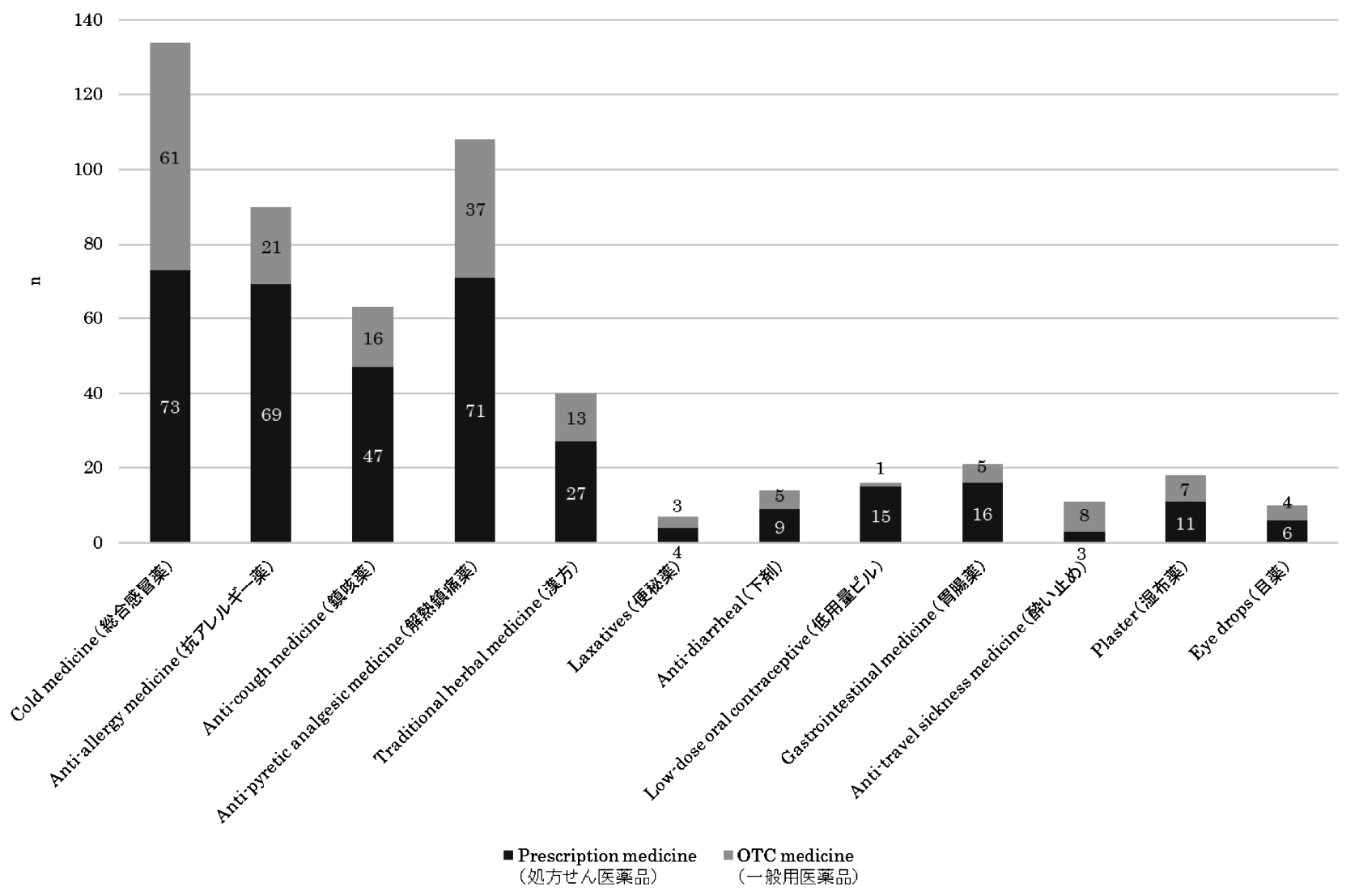

Figure 1 Types of medicines for which athletes have consulted the participants 
were more likely to be male, there was no difference in other background factors, such as age, workplace, or work area.

For the question "What kind of anti-doping activities are you doing now?", 616 (73.2\%) of the participants answered with "nothing in particular," while $156(18.5 \%)$ reported that they were providing information and enlightenment activities during consultations with athletes. Additionally, 58 (6.9\%) of the respondents reported that they provided education on the proper use of medicines and anti-doping. Twentythree $(2.7 \%)$, ten $(1.2 \%)$, and two $(0.2 \%)$ pharmacists provided information and awareness activities at regional-level competitions held in prefectures, at national-level competitions, and at international competitions, such as the world championships and Olympics, respectively.

Among all respondents, 180 (21.4\%) had consultations with athletes regarding medication use and 42
(5.0\%) had consultations regarding nutritional supplement use. Accredited sports pharmacists received more medication consultations $(\mathrm{p}<0.001)$ and nutritional supplement consultations $(\mathrm{p}<0.001)$ than did nonsports pharmacists; $18.7 \%$ of non-sports pharmacists also had medication consultations with athletes. Figure 1 shows the types of medicines for which athletes had consulted the participants.

A significant difference was seen between accredited sports pharmacists and other pharmacists regarding the information sources used in anti-doping consultations. Specifically, sports pharmacists frequently referred to the WADA's Prohibited List $(p=0.009)$, the Global DRO $(\mathrm{p}<0.001)$, and the Japan Pharmaceutical Association's anti-doping hotline $(\mathrm{p}=0.001)$ (Japan Pharmaceutical Association, 2018). In contrast, a significant number of non-sports pharmacists gave antidoping advice to athletes based on information from books and magazines $(p=0.047)$ (Table 2$)$.

Table 2 Information sources for anti-doping consultation (medicine) according to the accreditation of sports pharmacist status.

\begin{tabular}{|c|c|c|c|c|}
\hline & $\begin{array}{l}\text { Total } \\
\text { (合計) } \\
\mathrm{n}=180\end{array}$ & $\begin{array}{l}\text { Sports pharmacist } \\
\text { (スポーツファーマ } \\
\text { シスト認定あり) } \\
\quad \mathrm{n}=45\end{array}$ & $\begin{array}{l}\text { Non-sports pharmacist } \\
\text { (スポーツファーマ } \\
\text { シスト認定なし) } \\
\mathrm{n}=135\end{array}$ & $\mathrm{p}$ \\
\hline & n $(\%)$ & n $(\%)$ & n $(\%)$ & \\
\hline $\begin{array}{l}\text { I judged from my knowledge about pharmacology. } \\
\text { (薬理学的に問題なさそうだと, 自身の知識で判断した) }\end{array}$ & $23(12.8 \%)$ & $8(17.8 \%)$ & $15(11.1 \%)$ & 0.302 \\
\hline $\begin{array}{l}\text { I checked the prohibited substances list of JADA (Japan Anti- } \\
\text { doping Agency).* } \\
\text { (JADAの禁止表を確認し，国際基準に載っていないもの } \\
\text { だと判断した) }\end{array}$ & $106(58.9 \%)$ & $34(75.6 \%)$ & $72(53.3 \%)$ & 0.009 \\
\hline $\begin{array}{l}\text { I checked the Global DRO (Drug Reference Online) site. } \\
\text { (Global DRO のサイトで得た情報から判断した) }\end{array}$ & $33(18.3 \%)$ & $27(60.0 \%)$ & $6(4.4 \%)$ & $<0.001$ \\
\hline $\begin{array}{l}\text { I checked internet sites (other than the Global DRO). } \\
\text { (インターネットを検索して得た情報から判断した（Global } \\
\text { DRO 以外)） }\end{array}$ & $52(28.9 \%)$ & $10(22.2 \%)$ & $42(31.1 \%)$ & 0.342 \\
\hline $\begin{array}{l}\text { I checked books and magazines. } \\
\text { (本や雑誌から得た情報から判断した) }\end{array}$ & $19(10.6 \%)$ & $1(2.2 \%)$ & $18(13.3 \%)$ & 0.047 \\
\hline $\begin{array}{l}\text { I asked another pharmacist who is not an accredited sports } \\
\text { pharmacist. } \\
\text { (スポーツファーマシスト資格を持っていない他の薬剤師 } \\
\text { から聞いた情報から判断した) }\end{array}$ & $3(1.7 \%)$ & $1(2.2 \%)$ & $2(1.5 \%)$ & 1.000 \\
\hline $\begin{array}{l}\text { I asked another pharmacist who is an accredited sports pharmacist. } \\
\text { (スポーツファーマシスト資格を持っている薬郕師から聞 } \\
\text { いた情報から判断した) }\end{array}$ & $19(10.6 \%)$ & $6(13.3 \%)$ & $13(9.6 \%)$ & 0.575 \\
\hline $\begin{array}{l}\text { I consulted the anti-doping hotline of the Japan Pharmaceutical } \\
\text { Association. } \\
\text { (薬剤師会に問い合わせをし，得た情報から判断した） }\end{array}$ & $19(10.6 \%)$ & $11(24.4 \%)$ & $8(5.9 \%)$ & 0.001 \\
\hline $\begin{array}{l}\text { I asked members of JADA (Japan Anti-doping Agency). } \\
\text { (JADA (日本アンチ・ドーピング機構) に問い合わせをし, } \\
\text { 得た情報から判断した) }\end{array}$ & $5(2.8 \%)$ & $2(4.4 \%)$ & $3(2.2 \%)$ & 0.600 \\
\hline
\end{tabular}

A chi-square test was performed, with the significance level set at $5 \%$.

* Originally, the prohibited list was published by WADA; JADA provided the Japanese version of the prohibited list. 
Table 3 Management of athletes' inquiries and confidence therein, according to the respondents' background.

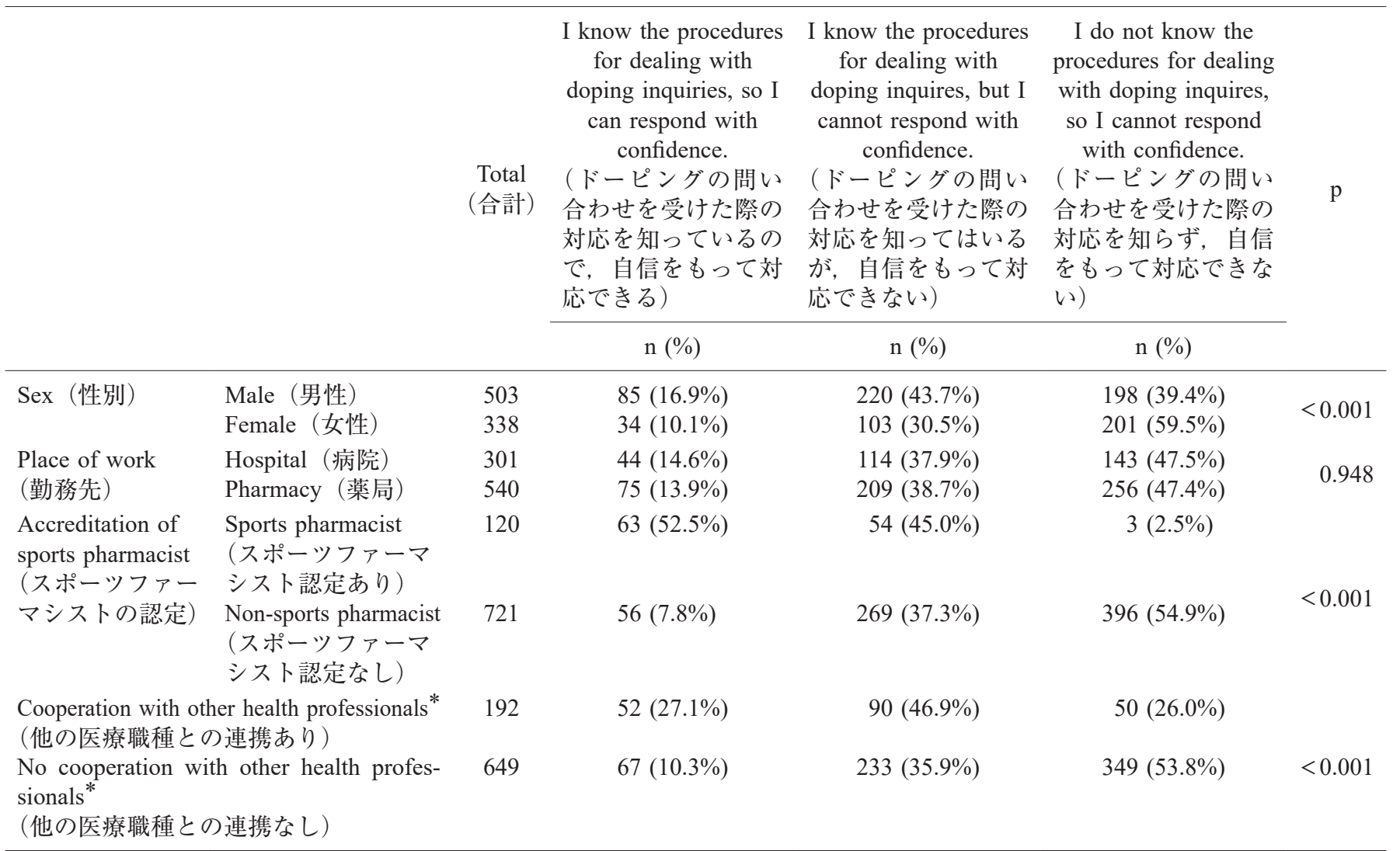

Chi-square tests were performed, with the significance level set at $5 \%$.

* Other health professionals include physicians and nutritionists.

We used the following question to determine whether pharmacists knew how to manage inquiries from athletes and their confidence in handling those inquiries: "An athlete asks, 'I would like to use this medicine (or nutritional supplement), but please let me know if it is considered doping.' Please choose the response closest to how you would answer at that time." A significantly greater proportion of male pharmacists $(\mathrm{p}<0.001)$, accredited sports pharmacists $(\mathrm{p}<0.001)$, and pharmacists in cooperation with other healthcare professionals, such as medical doctors and dietitians $(p<0.001)$, reported that they were confident in handling these inquiries (Table 3).

\section{Discussion}

We conducted a questionnaire survey targeting pharmacists working in medical facilities (hospitals and pharmacies), aiming to assess the actual conditions related to pharmacists' provisions of anti-doping activities in Japan. The survey showed that $21.4 \%$ of all pharmacists and $18.7 \%$ of non-sports accredited pharmacists had received inquiries from athletes re- garding medication use as a part of anti-doping activities.

Ten years have passed since the accredited sports pharmacist system was launched in 2009, and the number of sports pharmacists has reached 9,530 as of April 2, 2019 (Sports Pharmacist, 2019). However, with the forthcoming Tokyo Olympics and Paralympics, pharmacists who wish to obtain this accreditation must often rely on a lottery selection for accreditation training. Even though accreditation is highly competitive, there is no difference in the accreditation rate of sports pharmacists in metropolitan and nonmetropolitan areas. Each year, the Japan Pharmaceutical Association provides support and guidance on anti-doping activities conducted by the local branch of the pharmaceutical association of the host prefecture of the National Sports Festival (the venue changes every year). This support stimulates interest in antidoping activities among local pharmacists (Japan Pharmaceutical Association, 2020).

Nearly $20 \%$ of pharmacists in the present study had provided information on anti-doping, despite not being sports pharmacists. Accordingly, even non-sports ac- 
credited pharmacists should be able to conduct antidoping consultations with athletes, using reliable sources, such as the Global DRO, WADA's Prohibited List, and Japan Pharmaceutical Association's hotline. Our results support those of a previous study which suggested that anti-doping education should be included in all pharmacists' university education, and integrated into their continuous education programs (Ambrose, 2011; Hooper et al., 2019; Shibata et al., 2017).

Many sports pharmacists use credible information sources, such as the WADA's Prohibited List, Global DRO, and Japan Pharmaceutical Association's hotline, to identify prohibited substances. Conversely, a number of pharmacists obtain their information from books and magazines. In this study, we could not obtain information regarding the specific book and magazine titles; nevertheless, prohibited substances are updated annually and these sources may not contain the latest information. Even top athletes have been reported to show doping violations for drugs on the newest prohibited list (BBC, 2016).

Our results showed that the types of medications that athletes frequently use in daily life were common cold medicines, antipyretic analgesics, antiallergic agents, and anti-cough agents. In particular, antipyretic analgesics and antiallergic drugs were often used by athletes during the Summer Olympic Games (Athens and Sydney). It was also revealed that about $10 \%$ of the athletes received alternative medicine during the Sydney Olympics (Huang et al., 2006; Tsitsimpikou et al., 2009). Common cold medications and anti-cough agents were also frequently seen during the 2018 Pyeongchang Olympics and Paralympics Winter Games (Stuart et al., 2019). The medicines used by athletes at international competitions, such as the Olympic Games, are usually medicines that Japanese pharmacists deal with daily. It is necessary for pharmacists to understand the trends of drugs commonly used by athletes and to learn more about the prohibited substances related to these drugs.

Common cold medicines received the most consultations, and half of these were over-the-counter (OTC) medications. For OTC medicines in Japan, registered sellers (non-pharmacists who sell some OTC medicines that are not considered high-risk) were likely to respond to requests for information in the absence of a pharmacist, making it necessary to educate registered sellers with relevant anti-doping information. In particular, we expect anti-doping lectures by sports pharmacists, as well as a list of OTC medications con- taining prohibited substances, to be effective education for registered sellers.

The usage of traditional herbal medicine was also reported in this study. The ingredients of traditional herbal medicines are often unclear when compared with those of western medicines; therefore, special attention should be paid to their use. A previous study reported that athletes' use of herbal/traditional medications increased the likelihood of inadvertent doping (Fernando et al., 2017).

Since many pharmacists work in drug stores and deal with nutritional supplements, pharmacists need a basic knowledge of nutrition. In the present study, $5.0 \%$ of the respondents engaged in consultations regarding nutritional supplements. While fewer inquiries were made for nutritional supplements than for medications, a previous study revealed that more than half of young athletes have taken nutritional supplements in the past year, and that nutritional supplements have become as familiar to athletes as medicines (Nakajima et al., 2018). According to a US study, community pharmacists wish to provide information related to the nutritional supplement intake of athletes, but lack of time and knowledge prevent them from these activities (Howard et al., 2018). The same study also showed, in cross-sectional study of athletes, that athletes did not regard pharmacists as information providers of sports supplements, but wished to ask them about supplements (Howard et al., 2018). It is expected that providing nutritional and supplement intake advice and support will become important duties for pharmacists. In addition, it is expected that more comprehensive nutritional guidance will be provided for athletes cooperating with sports nutritionists, who can provide practical nutritional guidance, including meals (Japan Sports Nutrition Association, 2020).

One in four of the responding pharmacists had conducted some form of anti-doping activity. These included not only the provision of information to individual athletes, but also broader educational activities on the proper use of medicines, regardless of the athlete's competition level. Anti-doping educational activities are pertinent, regardless of the competition level, and these activities are expected to extend to school health activities conducted by school pharmacists (Ambrose, 2011). School health activities enable pharmacists to strengthen their cooperation with other healthcare professionals, such as school doctors and nutritionists. These activities are especially important for community pharmacists who have fewer opportu- 
nities to collaborate with other healthcare professionals than do hospital pharmacists.

It is necessary for sports pharmacists to understand the needs of athletes and provide health support through their activities, but collaboration with other medical professionals is essential for health issues that cannot be resolved by sports pharmacists alone. Multi-sector collaborations, such as pharmacists working with medical doctors, nurses, and dietitians, have been effective in solving various issues of patient care (Celio et al., 2018; Takhar et al., 2016). Health support for athletes should not be limited to simply providing information on prohibited drugs, but should also include providing education on correct nutritional intake (e.g., supplement use) and health issues specific to athletes (e.g., muscle and bone repair mechanisms), which requires collaboration with medical doctors and nutritionists (Ambrose, 2011). According to our results, pharmacists who collaborate with other healthcare professionals, such as medical doctors and dietitians, tend to be more familiar and confident in their interactions with athletes. Getting pharmacists more actively engaged in supporting athletes may strengthen the coordination system with other professionals involved in anti-doping. To achieve this, it is necessary to make the existence of sports pharmacists known not only to athletes, but also to other healthcare professionals. This study did not investigate specific multi-sectoral collaborations among healthcare professionals. To provide more effective health support, it is necessary to clarify specific examples of multi-sectoral cooperation activities in health support for athletes through further qualitative research.

Although pharmacists are medical professionals, they are chosen less often for anti-doping consultations than are medical doctors and coaches (Yamaguchi et al., 2016). Pharmacists should be more active in promoting their role in anti-doping. As a result of this study, we confirmed that sports pharmacists, who receive continual education, have knowledge of the proper sources of anti-doping information and know how to provide this information to athletes. Our results also showed that information sharing between sports and non-sports pharmacists is lacking. It is expected that more pharmacists will be able to respond to athletes with confidence if the recognition of sports pharmacists is expanded to non-sports pharmacists, and if information sharing between sports and nonsports pharmacists becomes more active.

This study has two possible limitations. First, al- though there are more female than male pharmacists in Japan, more male pharmacists participated in this study. We considered that the reasons for this reversal in the male-female ratio relate to the male-female ratio of the internet research company registrants and the difference between the sexes in the response rate; however, these details are unknown. Second, the results of this study showed that male pharmacists had a significantly higher acquisition rate of sports pharmacist accreditation than did female pharmacists, which may have biased the result regarding more confidence dealing with athletes in male pharmacists than in female pharmacists.

This study revealed the actual anti-doping activities conducted by pharmacists in Japan as the country approaches the Olympics and Paralympics. As many athletes worldwide will gather in Japan during the Olympic year, pharmacists in Japan should enhance the health support of athletes. Anti-doping education for all pharmacists involved in clinical practice and a system for coordination with other occupations are considered effective in achieving this enhancement.

\section{Conclusion}

It has become clear that while pharmacists do conduct consultations with athletes in general, there is a problem regarding the method of anti-doping education. Since accredited sports pharmacists choose more reliable sources of anti-doping information than non-accredited sports pharmacists do, athletes should, ideally, visit facilities with enrolled accredited sports pharmacists when they need medication support (especially anti-doping support). For pharmacists, further education is needed at universities and on the job, as pharmacists have trouble with effectively providing information to athletes on anti-doping. Additionally, the promotion of multi-sectoral collaborations among healthcare professionals that include pharmacists could create an athlete-friendly environment in the field of medication support.

\section{Acknowledgement}

This work was in part supported by the "Private University Research Branding Project" from MEXT.

\section{References}

Ambrose, P. J. (2011). Educational opportunities and anti-doping roles and responsibilities for pharmacists. Yakugaku Zasshi, 131: 1761-1764.

BBC (2016). Maria Sharapova failed drugs test at Australian 
Open. https://www.bbc.com/sport/tennis/35750285 (accessed 2020-06-12).

Celio, J., Ninane, F., Bugnon, O., and Schneider, M. P. (2018). Pharmacist-nurse collaborations in medication adherenceenhancing interventions: A review. Patient Educ. Couns., 101: 1175-1192.

Fernando, A. D. A., Bandara, L. M. H., Bandara, H. M. S. T., Pilapitiya, S., and de Silva, A. (2017). A Descriptive Study of Self-Medication Practices Among Sri Lankan National Level Athletes. BMC Res. Notes, 10: 257.

Hooper, A. D., Cooper, J. M., Schneider, J., and Kairuz, T. (2019). Current and potential roles in sports pharmacy: A systematic review. Pharmacy, 7: E29.

Howard, M. S., DiDonato, K. L., Janovick, D. L., Schroeder, M. N., Powers, M. F., Azzi, A. G., and Lengel, A. J. (2018). Perspectives of athletes and pharmacists on pharmacist-provided sports supplement counseling: An exploratory study. J. Am. Pharm. Assoc., 58: S30-36.e2.

Huang, S. H., Johnson, K., and Pipe, A. L. (2006). The Use of Dietary Supplements and Medications by Canadian Athletes at the Atlanta and Sydney Olympic Games. Clin. J. Sport Med., 16: 27-33.

Japan Anti-doping Agency (2020a). "List of domestic competitions for which TUE pre-application is required." https://www. playtruejapan.org/code/tue.html (accessed 2020-06-12) (in Japanese).

Japan Anti-doping Agency (2020b). Sports pharmacist. https:// www.playtrue2020-sp4t.jp/static/sportspharmacist/ (accessed 2020-06-12).

Japan Pharmaceutical Association. Consultations of anti-doping hotline. (2018). https://www.nichiyaku.or.jp/activities/antidoping/news.html (accessed 2020-06-12) (in Japanese).

Japan Pharmaceutical Association. Anti-Doping Guidebook for Pharmacists 2020. (2020). https://www.nichiyaku.or.jp/activities/ anti-doping/about.html (accessed 2020-06-12) (in Japanese).

Japan Sports Nutrition Association (2020). Sports Dietitian. https:// www.jsna.org/about/ (accessed 2020-06-12) (in Japanese).

Martínez-Sanz, J. M., Sospedra, I., Ortiz, C. M., Baladía, E., Gil-Izquierdo, A., and Ortiz-Moncada, R. (2017). Intended or unintended doping? A review of the presence of doping substances in dietary supplements used in sports. Nutrients, 9: 1093.

Nakajima, R., Onuma, N., Abe, M., and Kamei, M. (2018). Involving pharmacists in Japanese athletes' self-medication. J. Sports Med. Doping Stud., 8: 3.

Shibata, K., Ichikawa, K., and Kurata, N. (2017). Knowledge of pharmacy students about doping, and the need for doping education: a questionnaire survey. BMC Res. Notes, 10: 396.

Shimokawa, K., Konishi, Y., Suzuki, Y., Wada, Y., Yamazaki, N., Kitahara, Y., and Ishii, F. (2014). A survey on the awareness of sports pharmacists and their roles I: Questionnaire survey of athletes. Jpn. J. Commun. Pharmacy, 2: 87-98 (in Japanese).

Sports Pharmacist (2019). "Accreditation of Sports Pharmacist Overview." https://www.sp.playtruejapan.org/acquire/index.html (accessed 2020-06-12) (in Japanese).

Stuart, M., Kwon, Y. I., and Rhie, S. J. (2019). Pharmacy services at the PyeongChang 2018 Olympic and Paralympic Winter Games. Br. J. Sports Med., 53: 1105-1110.

Takhar, A., Herbert, J., Plum, R., Lad, M., Manger, D., Murdoch, T., Patel, V., and Tanna, P. (2016). SWEETWISE: developing a multi-professional approach to diabetes mellitus. Prim. Health Care Res., Dev. 17: 107-113.

Tokyo 2020 (2020). Anti-Doping. https://tokyo2020.org/en/games/ anti-doping/ (accessed 2020-06-12).

Tsitsimpikou, C., Tsiokanos, A., Tsarouhas, K., Schamasch, P., Fitch, K. D., Valasiadis, D., and Jamurtas, A. (2009). Medication Use by Athletes at the Athens 2004 Summer Olympic Games. Clin. J. Sport Med., 19: 33-8.

World Anti-doping Agency (2019). Anti-doping testing figures report. https://www.wada-ama.org/en/resources/laboratories/antidoping-testing-figures-report (accessed 2020-06-12).

World Anti-doping Agency (2020). The Code. https://www.wadaama.org/en/what-we-do/the-code (accessed 2020-06-12).

Yamaguchi, T., Horio, I., Goto, M., Miyauchi, Y., and Izushi, F. (2016). Clarification of the Relationship Between Awareness of Doping of Competitive Sports Coaches and Their Instructions to Prevent Doping. Yakugaku Zasshi, 136: 1185-1193 (in Japanese).

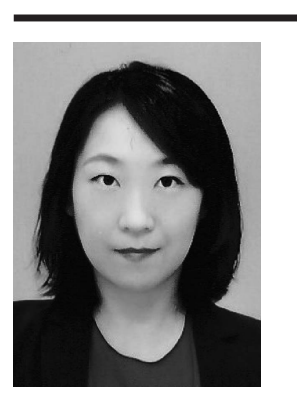

Name:
Rie Nakajima

Affiliation:

School of Pharmacy, Nihon University

\section{Address:}

7-7-1 Narashinodai, Funabashi, Chiba 274-8555, JAPAN

Brief Biographical History:

Apr 2013-Present Assistant Professor, School of Pharmacy, Nihon University

Apr 2011-Mar 2013 Pharmacist, Futaba Pharmacy, Yakujyu Co., Ltd.

Mar 2007 Master of Medical Science, Graduate School of Tokyo Medical and Dental University

Apr 2004-Mar 2005 Pharmacist, Department of Pharmacy, St. Margaret Hospital

Main Works:

- Nakajima, R. and Shiragami, M. (2018). Research on Community Resident's Awareness and Needs for the Services Offered at Primary Care Pharmacies. Jpn. J. Soc. Pharm., 37(1): 9-18. (in Japanese)

-Nakajima, R., Oki, F., and Shiragami, M. (2017). Evaluation of a Newly Developed Post Marketing Surveillance Method to Verify the Efficacy and Safety of Rx-to-OTC Switch Drugs. Jpn. J. Drug. Inform., 19(3): 121-126

- Nakajima, R., Nakamura, K., Takano, T., Seino, K., and Inose, T. (2007). Improvements in health by consultations using mobile videophones among participants in a community health promotion programme. J. Telemed. Telecare, 13(8): 411-415

Membership in Learned Societies:

- The Pharmaceutical Society of Japan

- Japanese Society of Social Pharmacy 